\title{
A Late Devonian Porolepiform fish(Holoptychius) and the age of the Kennebecasis Formation, southern New Brunswick, Canada
}

\author{
Randall F. Miller ${ }^{1^{*}}$ and Martin D. Brazeau ${ }^{2}$ \\ 1. Steinhammer Palaeontology Laboratory, New Brunswick Museum, Saint John, New Brunswick E2K 1E5 Canada \\ 2. Subdepartment of Evolutionary Organismal Biology, Department of Physiology and Developmental Biology, \\ Evolutionary Biology Centre, Uppsala University, Norbyvägen 18A, SE-752-36, Uppsala, Sweden \\ ${ }^{*}$ Corresponding author: $<$ Randall.Miller@nbm-mnb.ca $>$
}

Date received: 13 December 2006 Date accepted: November 1, 2007

\begin{abstract}
The occurrence of Holoptychius from southern New Brunswick, Canada, adds a new locality to eastern North America and suggests the assignment of a Late Devonian age for the Kennebecasis Formation. The formation has been considered Early Carboniferous based on a plant assemblage including Lepidodendron corrugatum and Aneimites acadica. Plant fossils likely originate from rocks overlying the Kennebecasis Formation, and are part of an unmapped westward extension of the Carboniferous Albert Formation to the Saint John area. The palaeobiogeographic implications of Holoptychius suggest the cryptic presence of a classic Late Devonian fish assemblage in southern New Brunswick and the possibility that tetrapod or near-tetrapod remains may be recovered from fossil-bearing horizons within the Kennebecasis Formation.
\end{abstract}

\section{RÉSUMÉ}

La manifestation de l'Holoptychius dans le Sud du Nouveau-Brunswick, Canada, ajoute un nouvel emplacement dans l'Est de l'Amérique du Nord et permet d'attribuer l'âge du Dévonien tardif à la Formation de Kennebecasis. La Formation était considérée comme une unité du Carbonifère précoce d'après un assemblage végétal comprenant le Lepidodendron corrugatum et l'Aneimites acadica. Les fossiles végétaux proviennent probablement de roches recouvrant la Formation de Kennebecasis et font partie d'un prolongement non cartographié de la Formation carbonifère d'Albert en direction ouest jusqu'à la région de Saint-Jean. Les répercussions paléobiogéographiques de la manifestation de l'Holoptychius laissent supposer la présence cryptique d'un assemblage de poissons classique du Dévonien tardif dans le Sud du Nouveau-Brunswick et la possibilité d'une récupération de restes de tétrapodes ou de quasi-tétrapodes des horizons fossilifères à l'intérieur de la Formation de Kennebecasis.

\section{[Traduit par la redaction]}

\section{INTRODUCTION}

A recently discovered vertebrate fossil belonging to a porolepiform fish suggests that the Kennebecasis Formation of southern New Brunswick (sensu Bailey and Matthew 1872) is Late Devonian in age. We provide a description of this new specimen identified as Holoptychius sp.indet. and review the existing fossil flora and fauna from the Kennebecasis Formation to reconcile the formation's current assignment to the Early Carboniferous (Williams et al. 1985; Barr and White 2004). Formation information can be found on-line in the Lexicon Database, Bedrock Nomenclature of New Brunswick. We consider the plant fossils used to date the Kennebecasis Formation as Carboniferous (Bell 1927; 1960) are not from this formation. The rocks yielding plant fossils originate from an overlying formation that may be an unmapped westward extension of the Carboniferous Albert Formation to the Saint John area. The occurrence of Holoptychius represents the only fossil known from the Kennebecasis Formation redbeds. Given an otherwise absence of fossils from the Kennebecasis Formation, age determinations are extremely difficult. Consequently, this discovery carries significant interest for stratigraphers and vertebrate palaeontologists.

The presence of Holoptychius in southern New Brunswick suggests the cryptic presence of a classic Late Devonian fish assemblage, in particular suggesting the possibility of finding arthrodire and antiarch placoderms and tristichopterid sarcopterygians (Schultze and Cloutier 1996), though none have been found to date. The vast majority of Devonian tetrapod localities are known to also yield remains of Holoptychius (Table 1 in Clack 2005).

\section{GEOLOGY AND STRATIGRAPHY}

The Kennebecasis Formation is a poorly dated clastic sedimentary sequence from southern New Brunswick that uncon- 
formably overlies Neoproterozoic and Early Paleozoic rocks (Fig. 1). The Kennebecasis fault separates the Kennebecasis Formation from Early Silurian rocks of the Kingston Group to the northwest and a fault separates Neoproterozoic and Cambrian rocks to the southeast (Barr and White 1998, 2004). The Kennebecasis Formation refers to a sequence of conglomerates and coarse-grained sandstones on the shores of the confluence of the Saint John and Kennebecasis Rivers in southern New Brunswick, Canada (Williams et al. 1985). The formation crops out in a northeasterly trend for a distance of about $40 \mathrm{~km}$. It has been dated as either Devonian or Early Carboniferous by various authors since Bailey and Matthew (1872) first used the name Kennebecasis conglomerates to describe the red conglomerate, red sandstone and red shale units found along the shore of the Kennebecasis River. Gesner (1839) provided an early description of these rocks, but the name Kennebecasis Formation was first used by Hayes (1927) who described the unit as exposed from the confluence of the Kennebecasis and Saint John Rivers, east to Hampton, and that it overlaid the Lower Carboniferous Albert Formation. Hayes and Howell (1937) later described it as being partly a lateral equivalent to the Albert Formation and reported that "a gradation from the gray sandstones, grits and shales of the Albert to the brown conglomerates, sandstones and shales of the Kennebecasis formation" could be seen in the vicinity of Moosehorn Creek east of Saint John (Hayes and Howell 1937, p. 106). They suggested the two formations were partly contemporaneous, but deposited in very different environments. However, it seems more likely that Hayes and Howell (1937) were describing the contact of the Albert Formation with the overlying Lower Carboniferous Weldon Formation (McLeod and Johnson 1999) which crops out in this region. The Albert Formation has been mapped as straddling the Devonian/Lower Carboniferous boundary in southeastern New Brunswick and is now considered Tournaisian in age (St. Peter 2003), and part of the Middle Devonian-Lower Carboniferous Horton Group (Williams et al. 1985).

The relationship of the Kennebecasis Formation to the Memramcook Formation to the east is uncertain. The Memramcook Formation is dated as Fammenian to Tournaisian and may be in part laterally equivalent to the Late Devonian to Early Carboniferous Albert Formation. Recent maps show the

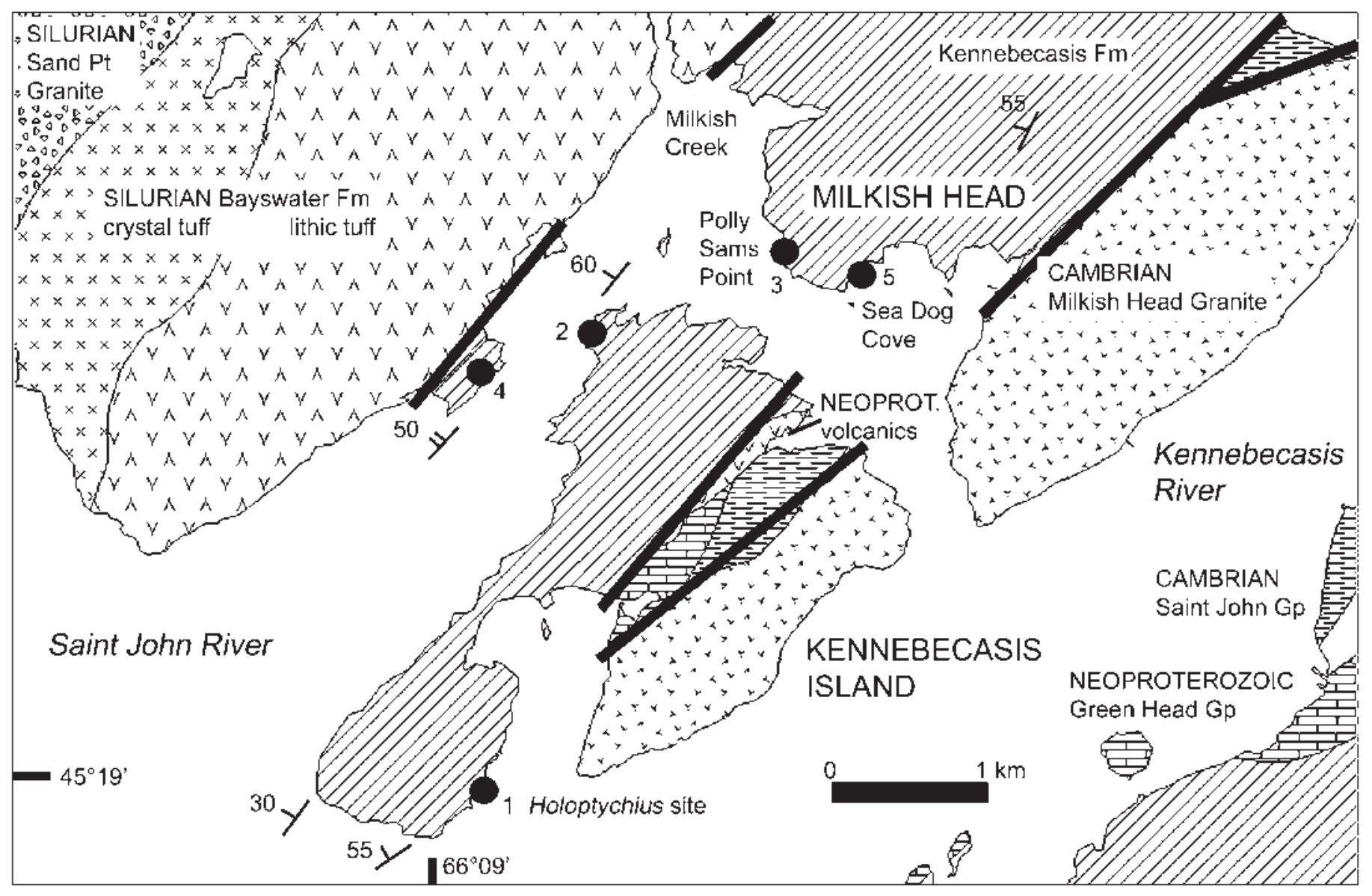

Fig. 1 Location of the Devonian specimen of Holoptychius in the Kennebecasis Formation, Kennebecasis Island, New Brunswick (1). Plant localities reexamined for this study $(2,3)$ and Geological Survey of Canada sites reported for plants (4) and Estheria (5) are likely Early Carboniferous age. Kennebecasis Formation indicated as currently mapped. 
Kennebecasis Formation as younger than the Memramcook Formation (Barr and White 2004); however, it may be equivalent to the lowest part of the Memramcook Formation.

The specimen described here was found on Kennebecasis Island in the red sandstones of the Kennebecasis Formation (Fig. 1, locality 1). The age of the Kennebecasis Formation (Williams et al. 1985) as described by Hayes (1927) and Hayes and Howell (1937), has been based on plants found in grey to brown siltstone and sandstone (Fig. 1, localities 2-4). The Early Carboniferous age was determined by Bell $(1927,1960)$ who used the plants to compare it to the Horton Group in Nova Scotia. The most recent geology maps place the Kennebecasis Formation as middle Lower Carboniferous (McLeod et al. 1994; Currie 1997; Barr and White 2004) or as part of a Late Devonian-Carboniferous package (Barr and White 1998; McLeod and Johnson 1999), and it is clear that the age is still uncertain. The discovery of a fossil vertebrate, here identified as Holoptychius sp., suggests a Late Devonian age, approximately equivalent to the Escuminac Formation of Gaspé (Miguasha) and the Perry Formation of southwestern New Brunswick. This age determination disagrees with the Early Carboniferous age based on plants (Bell 1960).

We argue below that the plant fossils are not from the Kennebecasis Formation as originally described by Bailey and Matthew (1872). A review of plant and arthropod fossils, our preliminary field studies, and early descriptions of the history of the mapping of the formation suggest that the Kennebecasis Formation, as defined (Bailey and Matthew 1872; Hayes 1927; Alcock 1938; Williams et al. 1985), does not include the plant and arthropod-bearing strata previously described from Kennebecasis Island (Copeland 1957; Bell 1960) and the Milkish Head area (Matthew 1907). The fossiliferous outcrops on the north shore of Kennebecasis Island (Fig. 1, locality 2) (Wilson 1914a, b; Bell 1960) and at Polly Sams Point (Fig.1, locality 3) on Milkish Head (NBM collection) that contain a "Lepidodendron" flora (Matthew 1907; Wilson 1914a; Bell 1960) and conchostracan remains (Copeland 1957) may be part of the Albert Formation, not currently recognized in the Saint John area. Further mapping will be required to determine the position of the plant-bearing beds. However, we tentatively retain them as Early Carboniferous and predict that the plant-bearing beds are at least equivalent in age to the Albert Formation and overlie red conglomerates and sandstones of the Kennebecasis Formation. Early suggestions by Ells (1906) that the Kennebecasis rocks (the red conglomerate-sandstone typical of the Kennebecasis Formation) are overlain by grey plant-bearing beds of Lower Carboniferous age, would seem to agree with this and will require observations from a direct geologic contact.

Almost all of the early work aimed at determining the age of the Kennebecasis Formation was published in annual reports of the Geological Survey of Canada with little detail concerning fossil locations. The most recent Survey map (Currie 1997) does not include the most notable fossil locations represented by GSC site numbers. Preliminary field assessment to discover plant localities described from the early 1900's suggest these localities are silty grey beds exposed on the north shore of the island (Fig. 1, locality 2) and brown sandstone beds at Polly Sams Point and Sea Dog Cove on Milkish Head (Fig. 1, locality 3). Plant-bearing beds on the north shore of Kennebecasis Island contain abundant plant fragments in a fine-grained rippled unit, typical of the Albert Formation further west near Norton (Falcon-Lang 2004). Similarly, Lepidodendropsis cf. L. corrugata recovered at Polly Sams Point and the flora identified by G.F. Matthew from 'Milkish' (New Brunswick Museum collection) are also typical of the Albert Formation. 'Milkish' samples likely originated from outcrops on the mainland at Milkish Head or west of Kennebecasis Island (Fig. 1, locality 4). The New Brunswick Museum collections also include a single, partial fish fossil from "Milkish, N.B.". The specimen (NBMG 3085), from a brown sandy sediment, belongs to an actinopterygian cf. Elonichthys, also typical of the Albert Formation fauna at Norton (Miller and McGovern 1997) and Albert Mines (Lambe 1910a). However, the material consists of only a patch of articulated scales and a partial median fin, and so is not very diagnostic. Nevertheless, all these specimens come from a greenish grey siltstone that is consistent with the lithology of Albert Formation beds, and are therefore of dubious provenance in the Kennebecasis Formation.

Sedimentary rocks containing Holoptychius comprise red sandstone interbedded with coarse, angular conglomerate typical of the Kennebecasis Formation. So far plants have not been recovered in these sandstone beds, with Holoptychius being the only fossil remains recovered.

\section{FOSSIL FISH FROM THE KENNEBECASIS FORMATION}

Examination of the red sandstones of the Kennebecasis Formation over the past 20 years by one of us (RFM) has failed to produce any fossil material. Generally considered unfossiliferous, the sandstone and conglomerate units of the Kennebecasis Formation have been largely unexplored for fossils. Field work in 2005 (RFM) resulted in a single locality producing vertebrate remains in a red sandstone interbedded with conglomerate. The specimen is reposited in the New Brunswick Museum palaeontology collection (NBMG).

\section{SYSTEMATIC PALAEONTOLOGY}

\author{
Osteichthyes Huxley, 1880 \\ Sarcopterygii Romer, 1955 \\ Porolepiformes Jarvik, 1942 \\ Holoptychius Agassiz, 1839 \\ Figs. 2a-c, 3a-c.
}

Age: Late Devonian, Kennebecasis Formation

Material: NBMG 13038 (New Brunswick Museum), a disarticulated skeleton (Fig. 2a) preserved mostly as a natural 
mould, consisting of isolated left and right dentaries, patches of scales (Fig. 2b, c), an isolated maxilla, left and right cleithra, left entopterygoid, gular plates and several dermal skull bones, most likely representing a single individual. The individual elements are well-preserved showing pit-lines, sensory canal pores, complete teeth and an unbroken denticle field on the entopterygoid. The dermal bones are ornamented by coarse, evenly distributed, raised tubercles of variable size.

Locality: Minor fine-grained sandstone unit of the Kennebecasis Formation, approximately 1 meter above the contact with a coarse conglomeratic facies, southeastern shore of Kennebecasis Island, New Brunswick, Canada (45⒚108N; $\left.66^{\circ} 08.624 \mathrm{~W}\right)$.

\section{Description}

The specimen (Fig. 3a-c) can be confidently assigned to the genus Holoptychius on the basis of its unique and highly characteristic scale morphology (Ørvig 1957) in combination with a number of other distinctive skull and postcranial characters that indicate both sarcopterygian and porolepiform identity. The scales of NBMG 13038 are comparable to those of Holoptychius described from numerous other localities (e.g., Jarvik 1972; Cloutier and Schultze 1996; Johanson and Ritchie 2000). The round scales are about $2 \mathrm{~cm}$ in diameter, with external ornament consisting of a series of vermiform, sub-parallel, and anteriorly anastomosing and converging ridges. The ridges are bordered anteriorly by a crescentic band of small tubercles (Fig. 3c). The basal (internal) face of the scales bears faint concentric rings and is marked by a field of small, irregularly distributed tubercles. It has been suggested that the scales of holoptychiid porolepiforms can sometimes match those of certain actinistians and rhizodontids (Jarvik 1950). However, following Ørvig (1957) these scales lack the central boss on the basal surface, by contrast with rhizodontids and tristichopterids, and the associated dermal bones do not agree morphologically with rhizodontids, tristichopterids or actinistians.

The right cleithrum is incompletely represented in the cast,
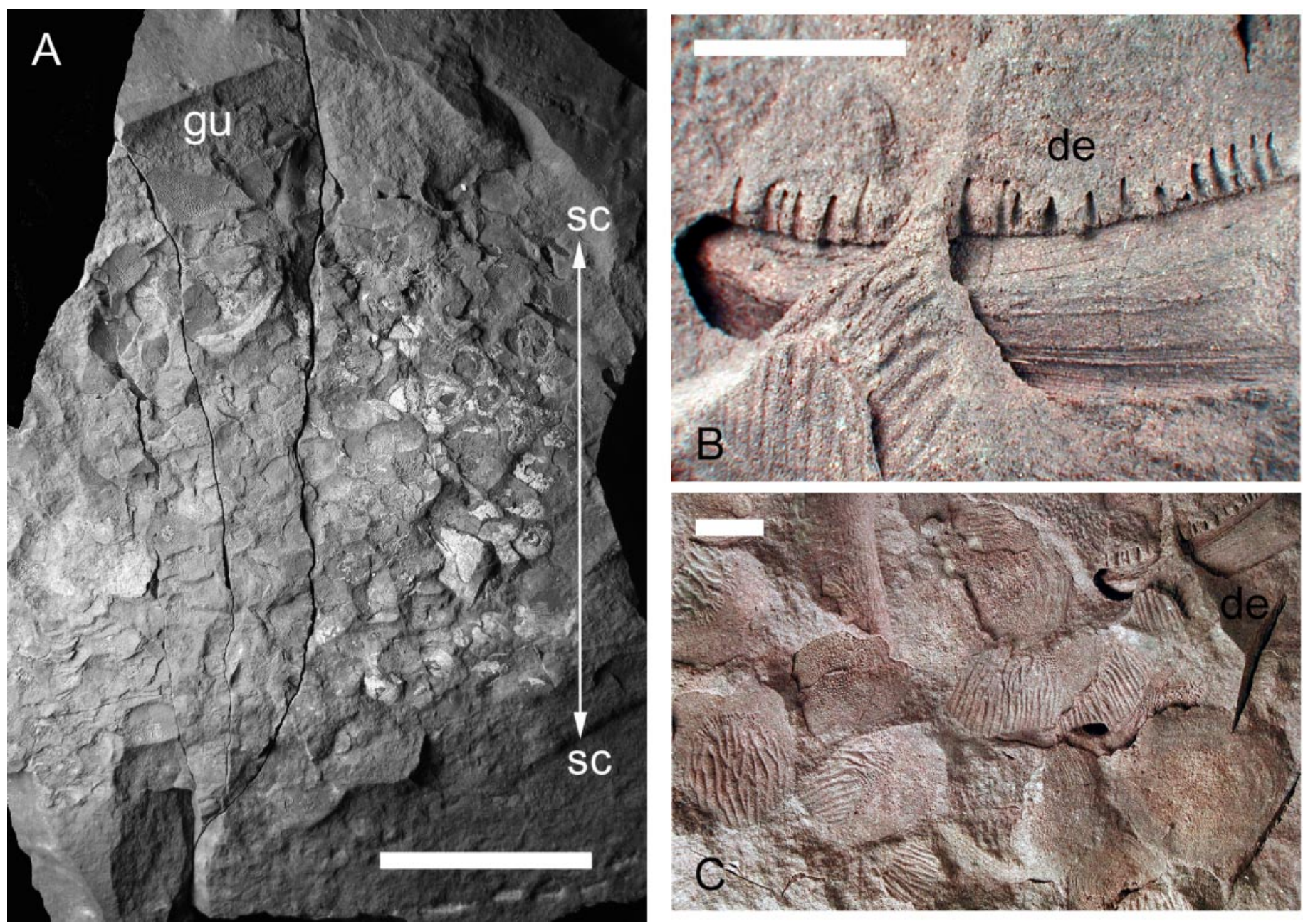

Fig. 2 A) largest block of NBMG 13038, Holoptychius sp. from the Kennebecasis Formation of southern New Brunswick. Approximately 75 to 100 scales preserved on the block. Scale $=10 \mathrm{~cm}$. B) close up of dentary. Scale $=1 \mathrm{~cm} . \mathrm{C}$ ) close up of scales adjacent to dentary. Scale $=1 \mathrm{~cm}$. Abbreviations: de., dentary; gu., gular plate; sc, area of scales indicated by arrows. 
but its overall shape is similar to that described for Holoptychius sp. from east Greenland (Jarvik 1972). By contrast with the tightly spaced vermicular ornament of Holoptychius from that assemblage, the ornament on the cleithrum of NBMG 13038 consists of more shallow, irregular pits. The element is unornamented in the region corresponding to the postbranchial lamina. The ventral lamina is anteroposteriorly short, tapering ventrally along its anterior margin where it bears a narrow overlap for the clavicle. Interestingly, this margin is somewhat concave, in contrast with that observed in Holoptychius from Miguasha (Cloutier and Schultze 1996). Rather, it is somewhat similar to specimens from East Greenland described by Jarvik (1950).
An isolated partial dentary visible in mesial view shows an overall similar morphology to Holoptychius, and bears a similar anterior dentary lamina that likely supported a tooth whorl (Jarvik 1972). This character is now considered to be a generalized feature of basal sarcopterygians as evidenced by the presence of a similar dentary lamina and accompanying internasal cavity in a number of putative stem-sarcopterygians (Zhu et al. 1999, 2001; Zhu and Yu 2002) and onychodonts (see Long 2001). This is a feature expected to be observed in Holoptychius and is not known in any actinistians or rhizodontids.

A single fourth infradentary is present and can be identified on the basis of a V-shaped pit line and notch in its anteroventral margin, corresponding to the margin of the infradentary

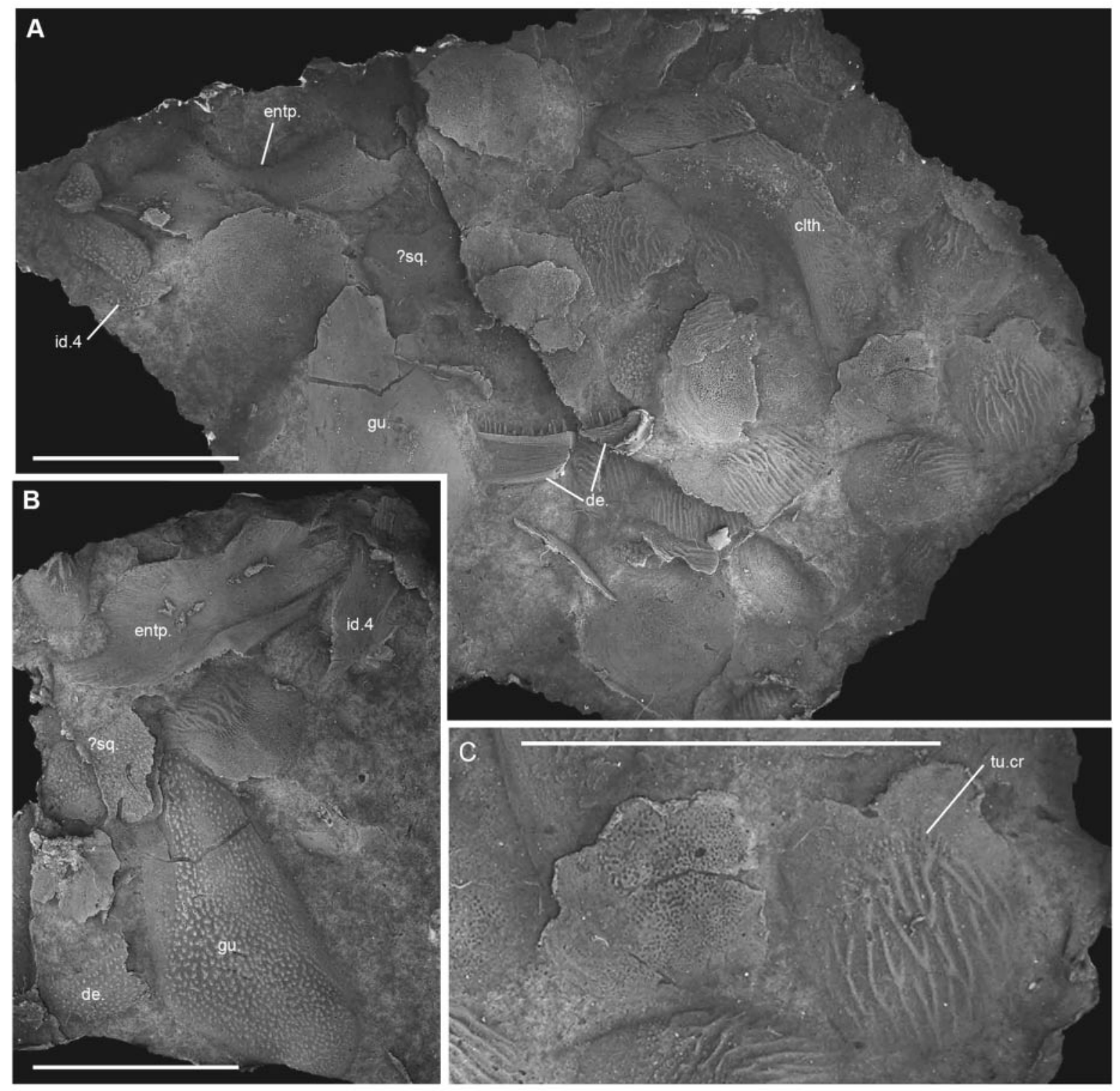

Fig. 3 Latex peels of part of NBMG 13038, Holoptychius sp. from the Kennebecasis Formation of southern New Brunswick. Largest part showing disarticulated partial skeleton (A); partial counterpart (B); close-up of two scales seen in A(C). Scale $=3 \mathrm{~cm}$. Abbreviations: clth., cleithrum; de., dentary; entp., entopterygoid; gu., gular plate; id.4, fourth infradentary (surrangular); ?sq., possible squamosal; tu.cr, tubercle crescent. 
foramen. Such foramina are known in the holoptychiid porolepiforms Holoptychius (Jarvik 1972), Laccognathus (Gross 1941), some Glyptolepis specimens (Ahlberg 1991) and some stem-group sarcopterygians (Zhu and Schultze 1997; Yu 1998; Zhu and Yu 2004). However, the overall morphology of the bone is identical to that known for Holoptychius (Jarvik 1972; Cloutier and Schultze 1996).

The gular plate (Fig. 3, gu.) is a triangular bone, broadest posteriorly and tapering anteriorly. Its proportions are broader than those described for Holoptychius by Jarvik (1972), but difficult to evaluate by comparison to the material from Miguasha. The median overlap surface of the gular is much broader than in other Holoptychius specimens and forms a distinctly concave margin into the ornamented portion of the bone. The dermal ornament is not evenly distributed over the surface, but rather is coarsest posteromedially. Anteriorly, the tubercles are finer and more widely spaced. Laterally, they are more densely spaced, and gradually get finer towards the posterior-most angle of the bone.

The entopterygoid is very well though incompletely preserved. It is essentially indistinguishable from that of other Holoptychius specimens.

\section{AGE OF THE KENNEBECASIS FORMATION}

If we assign the Kennebecasis Formation to the Devonian based on the presence of Holoptychius, what of the flora and fauna previously included in this formation? The age of the rocks has been considered Lower Carboniferous or Devonian based on interpretations of the plants. The Devonian age was a result of work by Matthew (1907) who wrongly applied Devonian ages to Carboniferous plants in southern New Brunswick (Falcon-Lang and Miller 2007). Plants were first collected during the summer of 1906 by R.W. Ells who reported that concerning the "rocks on Kennebecasis bay, they were found to be overlaid conformably by grey sandstones, grits and shales, which contain flora of Devonian types. A large collection of these plant fossils was made and examined by Dr. G.F. Matthew of Saint John, and their Devonian facies clearly determined. As these grey beds are unquestionably above the Perry dark red conglomerates the Devonian age of these is still more clearly defined." (Ells 1906, p. 132). Matthew (1907) noted the plants in his review of new species of Silurian and Devonian plants. Interest in the age of the Kennebecasis rocks had to do with the Devonian versus Late Carboniferous age controversy concerning the nearby outcrops at 'Fern Ledges'. At the time there was considerable and heated discussion about the age of plant-bearing beds in Saint John. There was significant disagreement about the age of the Late Carboniferous 'Fern Ledges' (Falcon-Lang and Miller 2007), which was considered Devonian by Matthew and others.

After making comparisons to recent work on the Perry Formation by David White, Ells (1906, p. 131) stated "One of the most important of the changes made in the geological work about St. John is the transference of the dark red conglomerates and sandstones of Kennebecasis bay, several miles north of the city, from the Lower Carboniferous to the Devonian" from their previous position published in 1879 (Bailey et al. 1880). Ells (1908) noted the Devonian age of the Kennebecasis rocks again in his report for 1907 as he laid out the results of continued mapping in southern New Brunswick.

Interest in the Kennebecasis fossils continued for a few years as Summary Reports for the years 1906, 1908 (Wilson 1909) and 1909 (Lambe 1910b; Wilson 1910) list several collections made by Geological Survey of Canada personnel. Henri Ami added 50 fossils from Kennebecasis Island to the Survey collections in 1907 (Whiteaves 1908); Robert Ells, Lawrence Lambe and William Wilson added Kennebecasis Island and Milkish Creek area fossils (part of a lot of 2,000 specimens) in 1909. Wilson (1914a) described the plant assemblage found earlier on Kennebecasis Island and identified by Matthew to include Lepidodendron corrugatum, L. gaspianum, L. chemungense, L. sternbergii, L. aculeatum, L. rimosum, and Psilophyton princeps. Although Matthew described the plant assemblage as Devonian, White (p. 408, in Wilson 1914a) who received a small collection to examine, believed that "The plant fragments you sent represent, almost without a doubt, a basal Lower Carboniferous flora...... Dr. Matthew, on the other hand, refers these rocks to the Upper Devonian ". White thought only one species of Lepidodendron could be identified. Wilson (1909, p. 184) described his collecting for 1908 at Kennebecasis Island in "rocks forming the western part of this island are grey sandstones, grits and shales: dipping N. $20^{\circ}, \mathrm{W}$. at an angle of $58^{\circ}$. The shale is mostly fine-grained, greenish grey, breaking in places into irregular concoidal pieces. These shaly beds contain many fern stems, cordaites, lepidodendra, fronds of ferns and separate pinules in good state of preservation.". Wilson then spent two weeks at Moosehorn Creek collecting in the Albert Formation. He compared the Kennebecasis Island specimens to those found further east at Moosehorn Creek, a site within the Albert Formation (Falcon-Lang 2004).

Our examination of the plant fossil locality on the north side of Kennebecasis Island agrees with the determination by White (in Wilson 1914a) and Bell (1960), that specimens represent an Early Carboniferous assemblage and that the rocks containing plants might be part of the Albert Formation which crops out less than $40 \mathrm{~km}$ east of Saint John along the Kennebecasis River valley near Bloomfield (McLeod and Johnson 1999). Bell (1960) listed six plants from Kennebecasis Island in his review of the Horton Group flora; Lepidodendropsis corrugata (Dawson), Nematophyllum sp., Aneimites acadica Dawson, Sphenopteris strigosa Bell,Diplotmema patentissimum (Ettingshausen), and Carpolithus tenellus (Dawson).

Hayes (1914) in his report on the geology of Saint John noted collections of the arthropod Estheria cf. E. dawsoni made by Kindle at Milkish Head (Fig.1) and that its range is confined to the Lower Carboniferous. Wilson (1915) in his Palaeobotany Report for 1914 recorded about 100 fossil plants collected by A.O. Hayes from Kennebecasis Island, mostly Lepidodendron corrugatum. The Summary Report for 1915 (Kindle 1916, p. 
200) listed as an addition to the Survey invertebrate collections "A crustacean fragment from the Carboniferous formation at Kennebecasis island, N.B." collected by Bell.

Hayes and Howell (1937, p. 107) reported Lepidodendron corrugatum and other plant remains from the northwestern shore of Kennebecasis Island which Bell (1927) used to suggest an Early Carboniferous age for the Kennebecasis Formation. In the same report Hayes and Howell (1937) noted Hayes had discovered abundant examples of the conchostracan Estheria dawsoni in a grey shale on the south shore of Milkish Head and on the most southerly point west of Sea Dog Cove (Fig. 1).

Copeland (1957) listed two species of concostrachans, "Asmussia" alta (sic) and A. tenella from GSC localities 1684, 3520 and 1684 respectively. GSC 1684 is described as the Lancaster Formation near Milkish Head, east of Saint John and collected by A.O. Hayes, 1913. GSC 3520 is reported to be a cove to the south of Milkish Head, Kennebecasis Bay near Saint John, collected by I.R. Jones, 1914. Copeland (1957) reported both of these as Upper Carboniferous, Cumberland Group, although both localities are in the Kennebecasis Formation as presently mapped. There may have been some error in the field notes for these sites as no Cumberland Group rocks have ever been identified from the Milkish Head area. Copeland (1957) did not list Euestheria (Estheria) dawsoni from either of these localities. Asmusia ranges from the Devonian to the Cretaceous. Asmusia membranacea is known from Miguasha (Martens 1996), occurring on clay bedding planes. Specimens labelled 'Estheria' (NBMG 10115-10117) from Milkish are found on thin clay slabs although the source beds of these fossils has not been located. The specimens have not been identified; however, they are not $A$. membranacea and resemble $A$. tenella figured by Copeland (1957).

This summary of the history of plant identification and dating of the Kennebecasis Formation leads us to believe the plant assemblages initially collected by Ells in 1906 and described by Matthew (1907), along with subsequent collections of plants and conchostracans, originate from Lower Carboniferous rocks overlying the Devonian red sandstone and conglomerate of the Kennebecasis Formation (Hayes 1927).

\section{DISCUSSION}

Holoptychius has a global distribution, known from the eastern United States (Catskill Formation, uppermost Famennian; Thomson 1976; Schultze and Cloutier 1996), Quebec (Escuminac Formation, lower Frasnian; Cloutier and Schultze 1996; Jarvik 1972), the Canadian Arctic (see Kiaer 1915 in Ørvig 1957), Greenland (Jarvik 1972), numerous localities in Europe, particularly the Baltic states, Russia, and Britain, and Australia (Young 1993; Schultze and Cloutier 1996). Since Schultze and Cloutier (1996) this genus has been described from the Frasnian of Colombia (Janvier and Villarroel 2000). The occurrence of definitive remains of Holoptychius in the Kennebecasis Formation lends strong support for the assignment of a Late Devonian age for this formation.
Conversely, this occurrence could be interpreted as the first known Carboniferous occurrence of Holoptychius. This conclusion is dubious. The reason an Early Carboniferous age assigned to the Kennebecasis Formation may be incorrect was discussed above. Although Bell (1960) described the lycopsids from Kennebecasis Island as an Early Carboniferous assemblage, it is possible they represent a Late Devonian flora such as that from Red Hill (Cressler and Pfefferkorn 2005) where Holoptychius also occurs. Further work on the plants is required. Holoptychius tends to be a rather abundant and common component of fish faunas, frequently represented by numerous scales. Such scales or any other evidence of Holoptychius is lacking from any of the fossil fish beds in the Albert Formation, which would be in close stratigraphic apposition with the Kennebecasis Formation.

Work by Greiner $(1977,1978)$ seemed to suggest that basal beds of the Albert Formation may have in fact been latest Devonian. This conclusion was initially based on an osteolepiform that was referred to the genus Latvius (Greiner 1977) known from the Late Devonian of the Baltic and Germany. However, Greiner cites no characters supporting this conclusion and a recent reappraisal of this and newly collected articulated material suggests a megalichthyid affinity, quite typical of many Carboniferous vertebrate faunas. Recent work by the authors, involving intensive collecting in the Albert Formation, shows that this formation is more typical of Carboniferous vertebrate assemblages, with Holoptychius or any porolepiforms entirely lacking. Spore analyses by St. Peter (2003) indicate a Tournaisian (Carboniferous) age for the Albert Formation beds containing the osteolepiform remains. Therefore, we do not see Greiner's conclusions as related to the problem we have addressed here.

The taxonomy of Holoptychius spp. is a subject requiring considerable revision as few apomorphies can be used to diagnose the many species (Cloutier and Schultze 1996). Consequently, we do not attempt to assign this material to any existing species nor do we attempt to establish it as a new taxon within the genus. The material is too incomplete to warrant a comparison with other known species of Holoptychius.

\section{CONCLUSION}

The Kennebecasis Formation is considered to be Late Devonian, not Early Carboniferous, based on the identification of the porolepiform fish Holoptychius sp. in red sandstone beds typical of the formation. Plant-bearing beds are lithologically distinct from the red sandstone and conglomerate of the Kennebecasis Formation as originally defined. Plant fossils, including Lepidodendron corrugatum and other Lower Carboniferous Horton Group flora, were likely collected above an unmapped contact from rocks equivalent to the Albert Formation. These facts help resolve the confusion surrounding the Middle Palaeozoic stratigraphy in this region. It further implies that the Kennebecasis Formation may be in part equivalent to the well-established Upper Devonian 
Memramcook Formation; however, we retain the distinction until proper stratigraphic work is accomplished. The presence of Holoptychius opens the possibility for the Kennebecasis Formation to yield additional Late Devonian fishes and possibly even tetrapods.

\section{ACKNOWLEDGEMENTS}

Thanks to D. McAlpine and N. Wood, (New Brunswick Museum) and J. Willett (Musée d'Histoire naturelle de Miguasha) for lending support in the field. G. Clément (Uppsala) for comments on the description and discussion of Holoptychius. P.E. Ahlberg and H. Blom (Uppsala) are thanked for helpful discussions. K.-L. Christensen supported several phases of this work. H.-P. Schultze (Kansas) and an anonymous reviewer provided helpful comments that significantly improved an earlier version of the manuscript. P. Janvier and G. Young are thanked for their review of the final manuscript. R.L. Carroll (Redpath Museum, McGill) provided encouragement for this work and graciously donated latex for casting NBMG 13038. R.F.M. gratefully acknowledges receipt of a Social Sciences and Humanities Research Council CURA grant (833-2003-1015). M.D.B. was supported by a Fonds québécois pour la recherche sur la nature et les technologies (FQRNT) scholarship and operating funds to P.E. Ahlberg from Vetenskapsrådet (Sweden) and in part by a New Brunswick Museum, G.F. Matthew Research Grant. R.F.M. thanks his Kennebecasis River kayak companions, S. Butler, G. Dubee, and B. Earle for their fieldwork support. This is a contribution to IGCP 491: Middle Palaeozoic Vertebrate Biogeography, Palaeogeography and Climate.

\section{REFERENCES}

Agassiz, J.L.R. 1839. Fishes of the Upper Ludlow rock. In The Silurian System, Part 1. Founded on geological researches in the counties of Solop, Hereford, Radnor, Montgomery, Caermarthen, Brecon, Pembroke, Monmouth, Gloucester, Worcester, and Stafford: with descriptions of the coal-fields and overlying formations. Edited by R.I. Murchison. London, John Murray, pp. 605-607.

Ahlberg, P.E. 1991. A re-examination of sarcopterygian interrelationships, with special reference to the Porolepiformes. Zoological Journal of the Linnean Society, 103, pp. 241-287.

Alcock, F.J. 1938. Geology of the Saint John region, New Brunswick. Geological Survey of Canada, Memoir 216. $146 \mathrm{p}$.

Bailey,L.W., and Matthew, G.F. 1872. Preliminary Report on the geology of Southern New Brunswick. Geological Survey of Canada, Report of Progress, 1870-71, pp. 13-240.

Bailey, L.W., MatTHew, G.F., AND Ells, R.W. 1880. Report on the geology of Southern New Brunswick, Embracing the counties of Charlotte, Sunbury, Queens, Kings, St. John, and
Albert. Geological Survey of Canada Report of Progress, 1878-79, pt. D, pp. 1-26.

BarR, S.M., AND White, C.E. 1998. Geology of the Kingston Peninsula (parts of NTS 21G/08, G/09, H/05, and H12), Kings and Queens counties, New Brunswick. New Brunswick Department of Natural Resources and Energy, Minerals and Energy Division, Plate 98-16, scale 1:50 000.

BARR, S.M., AND WHITE, C.E. 2004. Bedrock geology of the Caledonian Highlands of southern New Brunswick. New Brunswick Department of Natural Resources, Minerals, Policy and Planning Division, Plate 2004-138, scale 1:100 000.

BELL, W.A. 1927. Outline of Carboniferous stratigraphy and geologic history of the Maritime Provinces of Canada. Transactions of the Royal Society of Canada, 21, pp. 75-108.

BELL, W.A. 1960. Mississippian Horton Group of Type Windsor-Horton District, Nova Scotia. Geological Survey of Canada, Memoir 314. 112 p.

Clack, J. 2005. The emergence of early tetrapods. Palaeogeography, Palaeoclimatology, Palaeoecology, 232, pp. 167-189.

Cloutier, R., AND Schultze, H.-P. 1996. Porolepiform fishes (Sarcopterygii). In Devonian Fishes and Plants of Miguasha, Quebec, Canada. Edited by H.-P. Schultze and R. Cloutier. Verlag Dr. Friedrich Pfeil, Munich, pp. 248-270.

Copeland, M.J. 1957. The Arthropod fauna of the Upper Carboniferous rocks of the Maritime Provinces. Geological Survey of Canada, Memoir 286. 110 p.

Cressler, III, W.L, and Pfefferkorn, H.W. 2005. A late Devonian isoetalean lycopsid, Otzinachsonia beerboweri, gen. et sp. nov., from north-central Pennsylvania, USA. American Journal of Botany, 92, pp. 1131-1140.

Currie, K.L. 1997. Geology, Saint John - St. George region, New Brunswick (parts of $21 \mathrm{G}$ and $21 \mathrm{H}$ ). Geological Survey of Canada, Open File 3418, scale 1: 100000.

ELLS, R.W. 1906. Southern New Brunswick. Geological Survey of Canada, Summary Report for 1906, pp. 131-139.

ElLS, R.W. 1908. Surveys in southern New Brunswick. Geological Survey of Canada, Summary Report for 1907, pp. 74-76.

Falcon-Lang, H.J. 2004. Early Mississippian lycopsid forests in a delta-plain setting at Norton, near Sussex, New Brunswick. Journal of the Geological Society, London, 161, pp. 969-981.

Falcon-Lang, H.J., AND Miller, R.F. 2007. Marie Stopes and the Fern Ledges of Saint John, New Brunswick. In The Role of Women in the History of Geology. Edited by C. Burek and B. Higgs. Geological Society of London, Special Publications, 281, pp. 277-245.

Gesner, A. 1839. First report on the Geological Survey of the Province of New Brunswick. Henry Chubb, St. John. 87 p.

Greiner, H. 1977. Crossopterygian fauna from the Albert Formation, New Brunswick, Canada, and its stratigraphicpaleoecologic significance. Journal of Paleontology, 51, pp. 44-56.

GreINER, H. 1978. Late Devonian facies inter-relationships in 
bordering areas of the North Atlantic and the palaeogeographic implications. Palaeogeography, Palaeoclimatology, Palaeoecology, 25, pp. 241-263.

Gross, W. 1941. Über den Unterkiefer einiger devonischer Crossopterygier. Abhandlungen der Preußichen Akademie der Wissenschaften, Mathematisch-naturwissenschaftliche Klasse, 7, pp. 1-51.

Hayes, A.O. 1914. Geology of the St. John map-area, New Brunswick. Geological Survey of Canada, Summary Report for 1913, pp. 228-243.

Hayes, A.O. 1927. Bituminous shales and other mineral occurrences in the vicinty of Sussex, New Brunswick. Geological Survey of Canada, Summary Report for 1925, Part C, pp. $125-131$.

HaYes, A.O., AND Howell, B.F. 1937. Geology of Saint John, New Brunswick. Geological Society of America, Special Papers Number 5. 146 p.

HuXley, T.H.1880. On the application of the laws of evolution to the arrangement of the Vertebrata, and more particularly of the Mammalia. Proceedings of the Zoological Society of London, 43, pp. 649-661.

Janvier, P., AND Villarroel, C. 2000. Devonian vertebrates from Colombia. Palaeontology, 43, pp. 729-763.

JARVIK, E. 1942. On the structure of the snout of crossopterygians and the lower gnathostomes in general. Zoologiska Bidrag, Uppsala, 21, pp. 235-675.

JaRviK, E. 1950. Middle Devonian vertebrates from Canning Land and Wegeners Halvö (East Greenland), Part II: Crossopterygii. Meddelelser om Grønland, 96, pp. 1-132.

JarVIK, E. 1972. Middle and Upper Devonian Porolepiformes from East Greenland with special reference to Glyptolepis groenlandica n. sp. Meddelelser om Grønland, 187, pp. 1-307.

Johanson, Z., And Ritchie, A. 2000. Rhipidistians (Sarcopterygii) from the Hunter Siltstone (Late Famennian) near Grenfell, NSW, Australia. Mitteilungen aus dem Museum für Naturkunde in Berlin, Geowissenschaftliche Reihe, 3, pp. 111-136.

KindLE, E.M. 1916. Report of the Stratigraphical Palaeontologist. Geological Survey of Canada, Summary Report for 1915, pp. 198-205.

Lambe, L.M. 1910a. Contributions to Canadian Palaeontology, Volume III, Part V. Palaeoniscoid fishes from the Albert Shales of New Brunswick. Canada Department of Mines, Memoir No. 3.69 p.

Lambe, L.M. 1910b. Palaeontology and Zoology. Geological Survey of Canada, Summary Report for 1909, pp. 269273.

LonG, J.A. 2001. On the relationships of Psarolepis and the onychodontiform fishes. Journal of Vertebrate Paleontology, 21, pp. 815-820.

Martens, T.H. 1996. Conchostraca (Phyllopoda, Crustacea) from the Escuminac Formation. In Devonian Fishes and Plants of Miguasha, Quebec, Canada. Edited by H.-P. Schultze and R. Cloutier. Verlag Dr. Friedrich Pfeil, Munich, pp. 112-113.
Matthew, G.F. 1907. On some new species of Silurian and Devonian plants. Transactions of the Royal Society of Canada, 3rd series, 1, pp. 185-197.

McLeod, M.J., AND Johnson, S.C. 1999. Bedrock geological compilation of the Sussex map area (NTS 21 H/12), Kings and Queens counties, New Brunswick. New Brunswick Department of Natural Resources and Energy, Minerals and Energy Division, Plate 99-21, scale 1:50 000.

McLeod, M.J., Johnson, S.C., ANd Ruitenberg, A.A. 1994. Geological map of southwestern New Brunswick. New Brunswick Department of Natural Resources and Energy, Mineral Resources, Map NR-5, scale 1:250 000.

Miller, R.F., AND McGovern, J.H. 1997. Preliminary report of fossil fish (Actinopterygii: Palaeonisciformes) from the Lower Carboniferous Albert Formation at Norton, New Brunswick(NTS $21 \mathrm{H} / 12$ ). In Current Research 1996. Edited by B.M.W. Carroll. New Brunswick Department of Natural Resources and Energy, Minerals and Energy Division, Mineral Resource Report 97-4, pp. 191-200.

ØRVIG, T. 1957. Remarks on the vertebrate fauna of the Lower Upper Devonian of Escuminac Bay, P.Q., Canada, with special reference to the Porolepiform Crossopterygians. Arkiv för Zoologi, 10, pp. 367-426.

Romer, A.S. 1955. Herpetichthyes, Amphibiodei, Choanichthyes or Sarcopterygii? Nature, 176, pp. 126.

Schultze, H.-P., AND Cloutier, R. 1996. Comparison of the Escuminac Formation ichthyofauna with other late Givetian/early Frasnian ichthyofaunas. In Devonian Fishes and Plants of Miguasha, Quebec, Canada. Edited by H.-P. Schultze and R. Cloutier. Verlag Dr. Friedrich Pfeil, Munich, pp. 348-368.

St. Peter, C. 2003. Revisions to Lower Carboniferous Horton Group stratigraphy in New Brunswick, Canada. In Abstracts with Programs, Geological Society of America, Northeastern Section 38th Annual Meeting, 35, p. 19.

Thomson, K. S. 1976. The faunal relationships of rhipidistian fishes (Crossopterygii) from the Catskill (Upper Devonian) of Pennsylvania. Journal of Paleontology, 50, pp. 1203-1208.

Whiteaves, J.F. 1908. Surveys in southern New Brunswick. Geological Survey of Canada, Summary Report for 1907, pp. 105-109.

Williams, G.L., Fyffe, L.R., Wardle, R.J., Colman-Sadd, S.P., AND BoeHner, R.C. 1985. Lexicon of Canadian Stratigraphy, Volume VI, Atlantic Region. Canadian Society of Petroleum Geologists, Calgary. 572 p.

WILson, W.J. 1909. Summary report dealing with the field work in connexion with the collection of palaeontological material from the Devonian and Lower Carboniferous of New Brunswick. Geological Survey of Canada, Summary Report for 1908, pp. 183-185.

WiLson, W.J. 1910. Palaeontological material from the Devonian and Carboniferous of southern New Brunswick. Geological Survey of Canada, Summary Report for 1909, pp. 274-276.

WiLson, W.J. 1914a. Summary report dealing with the field 
work in connexion with the collection of palaeontological material from the Devonian and Lower Carboniferous of New Brunswick. Geological Survey of Canada, Summary Report for 1912, pp. 407-410.

WiLson, W.J. 1914b. Palaeobotany. Geological Survey of Canada, Summary Report for 1913, pp. 322-326.

Wilson, W.J. 1915. Palaeobotany. Geological Survey of Canada, Summary Report for 1914, pp. 130-134.

Young, G. 1993. Middle Paleozoic macrovertebrate biostratigraphy of eastern Gondwana. In Palaeozoic Vertebrate Biostratigraphy and Biogeography. Edited by J.A. Long. Johns Hopkins University Press, pp. 208-251.

Yu, X. 1998. A new porolepiform-like fish, Psarolepis romeri, gen. et. sp. nov. (Sarcopterygii, Osteichthyes) from the Lower Devonian of Yunnan, China. Journal of Vertebrate Paleontology 18, pp. 261-274.
Zhu, M., ANd Schultze, H.-P. 1997. The oldest sarcopterygian fish. Lethaia 30, pp. 293-304.

Zhu, M., AND Yu, X. 2002. A primitive fish close to the common ancestor of tetrapods and lungfish. Nature 418, pp. 767-770.

ZHU, M., AND YU, X. 2004. Lower jaw character transitions among major sarcopterygian groups - a survey based on new materials from Yunnan, China. In Recent Advances in the Origin and Early Radiation of Vertebrates. Edited by G. Arratia, M.V.H. Wilson, and R. Cloutier. Verlag Dr. Friedrich Pfeil, Munich, pp. 271-286.

Zhu, M., Yu, X., AND Janvier, P. 1999. A primitive fossil fish sheds light on the origin of bony fishes. Nature 397, pp. 607-610.

Zhu, M., Yu, X., ANd Ahlberg, P. 2001. A primitive sarcopterygian fish with an eyestalk. Nature 410, pp. 81-84.

Editorial responsibility: Ron K. Pickerill 